\title{
Shear-Hosted Uranium Deposits: A Review
}

\author{
Andy Wilde 1,2 (1) \\ 1 CET, University of Western Australia, Crawley, WA 6009, Australia; wildegeoscience@gmail.com \\ 2 Deep Yellow, Subiaco, WA 6008, Australia
}

Received: 20 August 2020; Accepted: 23 October 2020; Published: 26 October 2020

check for updates

\begin{abstract}
A group of uranium deposits is described that is hosted within polyphase shear zones. The group is economically significant, collectively containing over 500,000 tonnes of uranium and several examples have been or are being mined. Over a hundred individual deposits are known widely spread over many countries. It is proposed that this group be assigned to a new shear-hosted uranium deposit category. Uranium deposition was superimposed upon intense and extensive feldspathic alteration formed during ductile deformation. This intense alteration has led to the alternative albitite-type or metasomatite-type nomenclature. The evidence is clear that in most cases uranium mineralization postdates regionally extensive feldspar alteration and is associated with a range of alteration assemblages which overprint early albite or K-feldspar dominant alteration. Abundance of hydrothermal zirconium and phosphate minerals is a common characteristic of this group which implies high activity of $\mathrm{F}$ and $\mathrm{P}$ during mineralisation, but the source of hydrothermal fluids remains uncertain. Also uncertain is the geodynamic setting of uranium mineralisation which is a consequence of absolute mineralisation age being poorly defined. Data from three of the four major districts are suggestive that mineralisation was a consequence of fluid migration along shears during regional compression. This paper reviews key aspects of the group in a mineral systems context, focussing on the four major districts of Kropyvnytskyi (Ukraine), Lagoa Real (Brazil), Mount Isa (Australia) and the Central Mineral Belt (Canada).
\end{abstract}

Keywords: uranium; shear zones; feldspathic alteration; potassic alteration; economically significant

\section{Introduction and Economic Significance}

There is a large group of uranium deposits hosted in mylonitic shear zones that have undergone multiple movement events and hydrothermal alterations [1-3]. This diverse group has previously been assigned to the 'metasomatite' or 'Na-metasomatite' categories [4] or the albitite-type grouping reflecting the fact that the deposits are associated with albitic alteration [3]. In this paper, however, I propose that the term 'shear-hosted' be applied to the group. Below, I review descriptive and genetic models for many of the larger and economically significant deposits.

A mineral systems approach is used to frame this discussion, whereby ore deposit formation is considered holistically in the context of the geodynamic evolution of the host terrane [5]. This includes consideration of the source or sources of melts or fluids, metals and ligands and processes responsible for driving melt- or fluid-assisted transfer of ore components from source to trap. Equally important are the geological processes required for focusing the flow of melt or hydrothermal fluid into depositional sites and the chemical and physical processes of metal deposition. An understanding of the potential for preservation of a mineral deposit is another key element in mineral systems thinking but is not discussed below. 


\section{Economic Significance}

The shear-hosted group collectively contains as much uranium as the better-known unconformity-type deposits but at a grade which is an order of magnitude lower (Tables 1 and 2; [3]). The uranium districts with the largest uranium endowment are Kropyvnytskyi in the Ukraine and Lagoa Real in Brazil (Figures 1-3; Table 1). Other important districts include Mount Isa (Queensland, Australia) and the Central Mineral Belt (Labrador, Canada). Resource data are not publicly available for all known deposits, but one of the largest deposits is Novokostantynivka in the Ukraine, at over 90,000 tonnes contained $\mathrm{U}_{3} \mathrm{O}_{8}$ (Figure 4; Table 2). The giant Itataia (Santa Quiteria) deposit in Brazil with a resource of over 80,000 tonnes $\mathrm{U}_{3} \mathrm{O}_{8}$ is probably a variant of the type which carries an unusually large volume (9 million tonnes) of hydrothermal fluorapatite [6]. The Elkon deposits (Russia) have a resource exceeding 300,000 tonnes $\mathrm{U}_{3} \mathrm{O}_{8}$ and have many features of the group, although the host rocks exhibit potassic rather than sodic alteration [7]. Mines exploiting this style of deposit occur in the Kropyvnytskyi (formerly Kirovograd) district of Ukraine (Smolino and Ingul) and at Lagoa Real in Brazil (Cachoeira, Engenho) and operated historically in the Beaverlodge district of Canada (Gunnar).

Table 1. Major shear-zone hosted uranium districts with approximate uranium endowment.

\begin{tabular}{ccccc}
\hline District & Country & Total $\mathbf{U}_{\mathbf{3}} \mathbf{O}_{\mathbf{8}}$ Tonnes & Deposits & Largest Deposit \\
\hline Kropyvnytskyi & Ukraine & 327,670 & 22 & Novokostantynivka \\
Lagoa Real & Brazil & 132,120 & 10 & Engenho \\
Mount Isa & Australia & 74,590 & 17 & Valhalla \\
Central Mineral Belt & Canada & 69,114 & 11 & Michelin \\
Bohemia & Czech Republic & 40,140 & 5 & Rozna \\
Beaverlodge & Canada & 38,557 & 7 & Gunnar \\
Arjeplog-Arvidsjaur & Sweden & 16,710 & 11 & Duobblon \\
Total & & 566,781 & 81 & \\
\hline
\end{tabular}

Table 2. Average grade and contained uranium of the top 20 shear-hosted uranium deposits.

\begin{tabular}{|c|c|c|c|c|c|}
\hline Deposit Name & Alternative Name & $\begin{array}{c}\text { Contained } t \\
\mathrm{U}_{3} \mathrm{O}_{8}\end{array}$ & $\begin{array}{c}\text { Grade } \% \\
\mathrm{U}_{3} \mathrm{O}_{8}\end{array}$ & Uranium District & Country \\
\hline Novokostantynivka & Novokonstantinovskoye & 93,626 & 0.14 & Kropyvnytskyi & Ukraine \\
\hline Centralnye & & 72,300 & 0.12 & Kropyvnytskyi & Ukraine \\
\hline Coles Hill & $\begin{array}{l}\text { Swanson Project } \\
\text { North and South }\end{array}$ & 59,742 & 0.06 & & USA \\
\hline Severynka & Severinskoye & 55,100 & 0.11 & Kropyvnytskyi & Ukraine \\
\hline Michelin & & 46,810 & 0.10 & $\begin{array}{c}\text { Central Mineral } \\
\text { Belt }\end{array}$ & Canada \\
\hline Valhalla-Odin & & 38,593 & 0.09 & Mount Isa & Australia \\
\hline Michurin & Ingul'skii mine & 29,760 & 0.10 & Kropyvnytskyi & Ukraine \\
\hline Vatutin & Smolino mine & 28,100 & 0.15 & Kropyvnytskyi & Ukraine \\
\hline Eldorado & $\begin{array}{l}\text { Fay, Ace, Verna, } \\
\text { Bolger }\end{array}$ & 27,769 & 0.22 & Beaverlodge & Canada \\
\hline Engehno & Anomaly 9 & 27,418 & & Lagoa Real & Brazil \\
\hline Rozna & & 27,120 & 0.28 & Bohemia & Czech Republic \\
\hline Zhovta Richka & Zheltorechenskoye & 22,113 & 0.14 & Kropyvnytskyi & Ukraine \\
\hline Cachoeira & Anomaly 13 & 20,305 & 0.35 & Lagoa Real & Brazil \\
\hline Eko Remaja & Kalan & 15,000 & & & Indonesia \\
\hline Modesto & Anomaly 7 & 14,380 & & Lagoa Real & Brazil \\
\hline Pidgaytsi & Podgaytsevskoe & 13,800 & 0.10 & Kropyvnytskyi & Ukraine \\
\hline Kitongo & Goble & 13,000 & 0.10 & & Cameroon \\
\hline Pershotravneve & Pervomayskoye & 12,870 & 0.10 & Kropyvnytskyi & Ukraine \\
\hline Zadni-Chodov & & 11,520 & & Bohemia & Czech Republic \\
\hline A238 & & 10,610 & 0.02 & & Mauritania \\
\hline
\end{tabular}




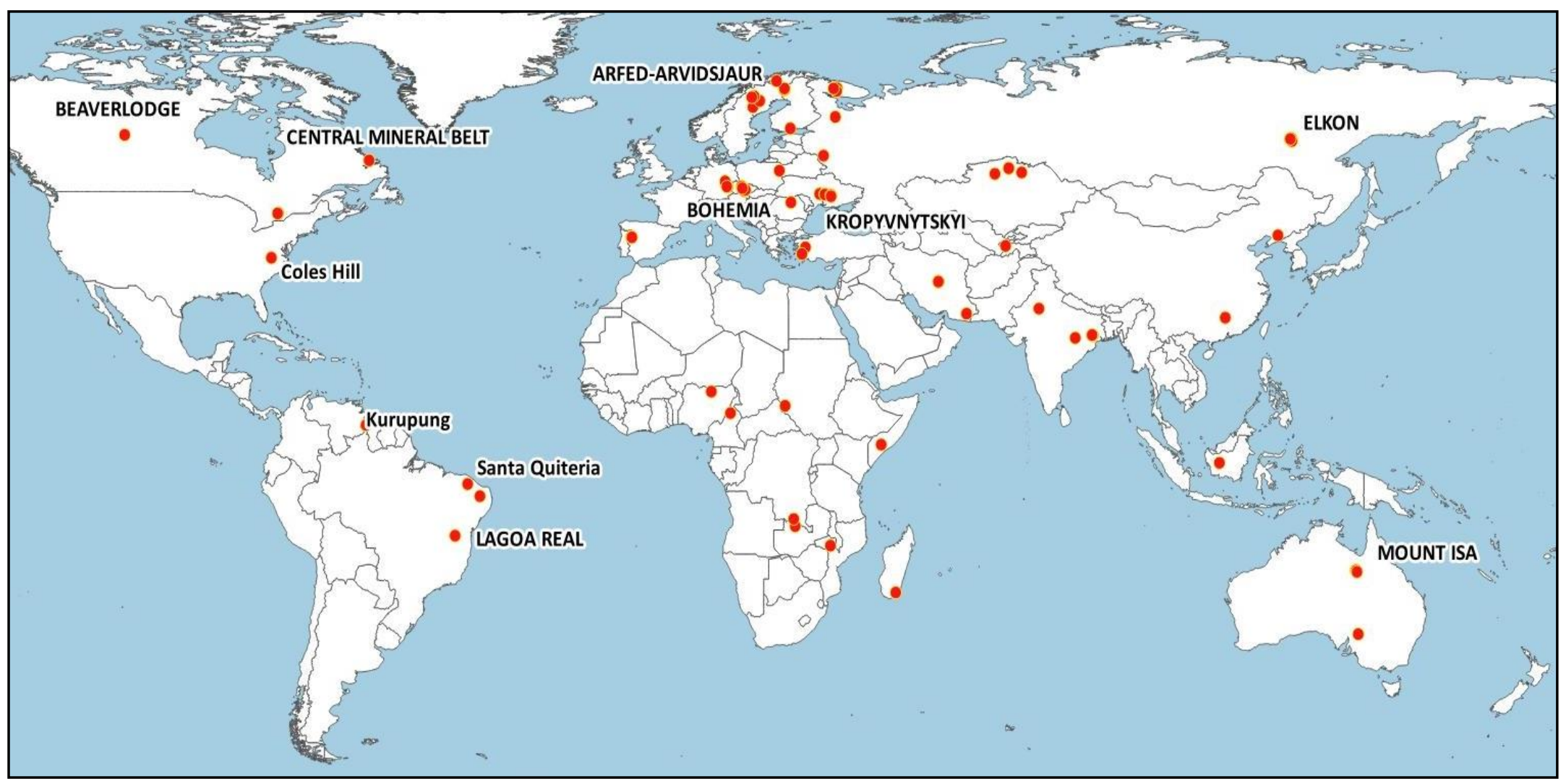

Figure 1. Location of major shear-zone hosted U deposits and districts. District names are capitalised. 

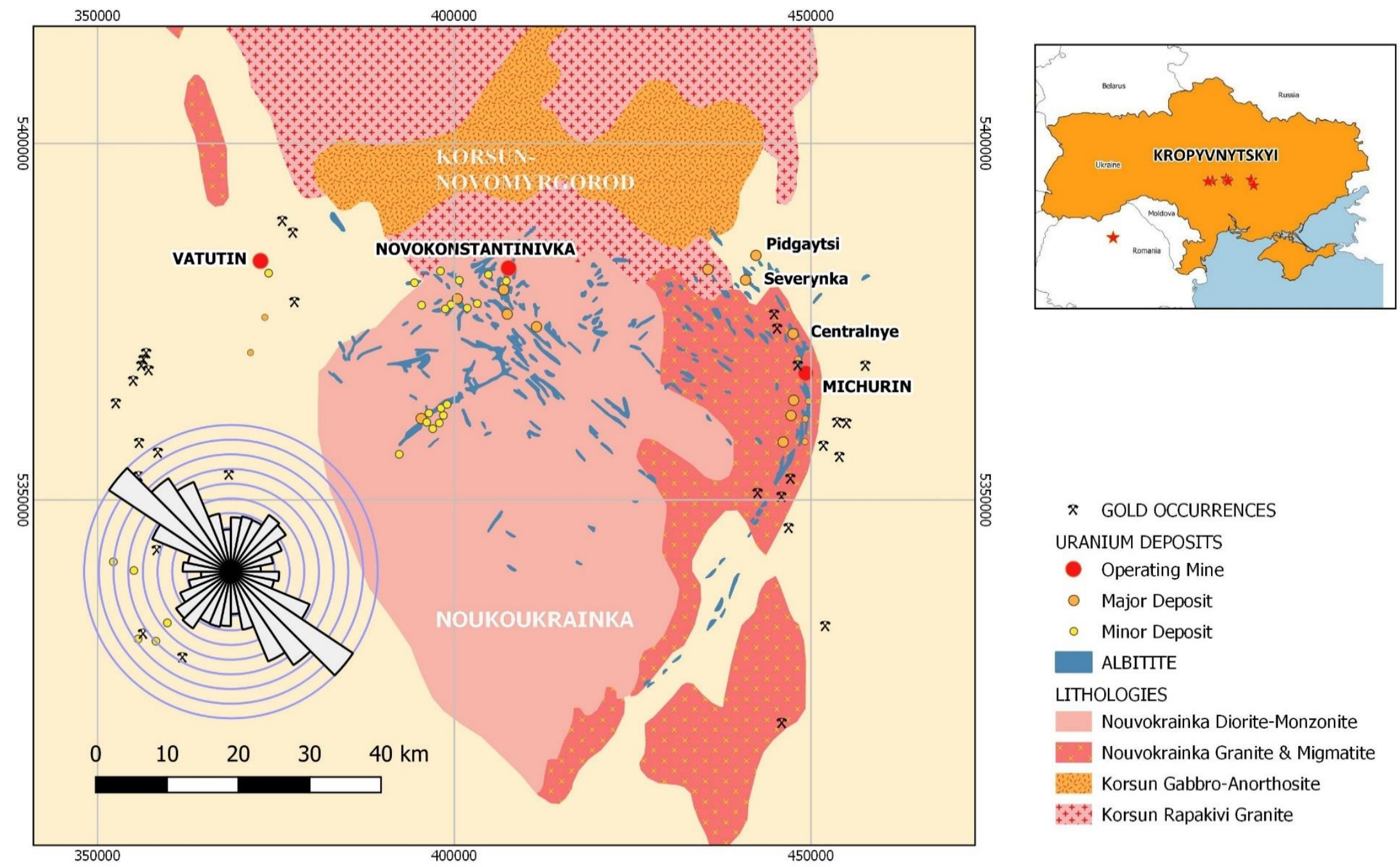

$\times$ GOLD OCCURRENCES

URANIUM DEPOSITS

- Operating Mine

- Major Deposit

- Minor Deposit

ALBITITE

LITHOLOGIES

Nouvokrainka Diorite-Monzonite

Nouvokrainka Granite \& Migmatite

Korsun Gabbro-Anorthosite

(t+++ Korsun Rapakivi Granite

Figure 2. Geological map of the Kropyvnytskyi district, Ukraine, based on [8]. 

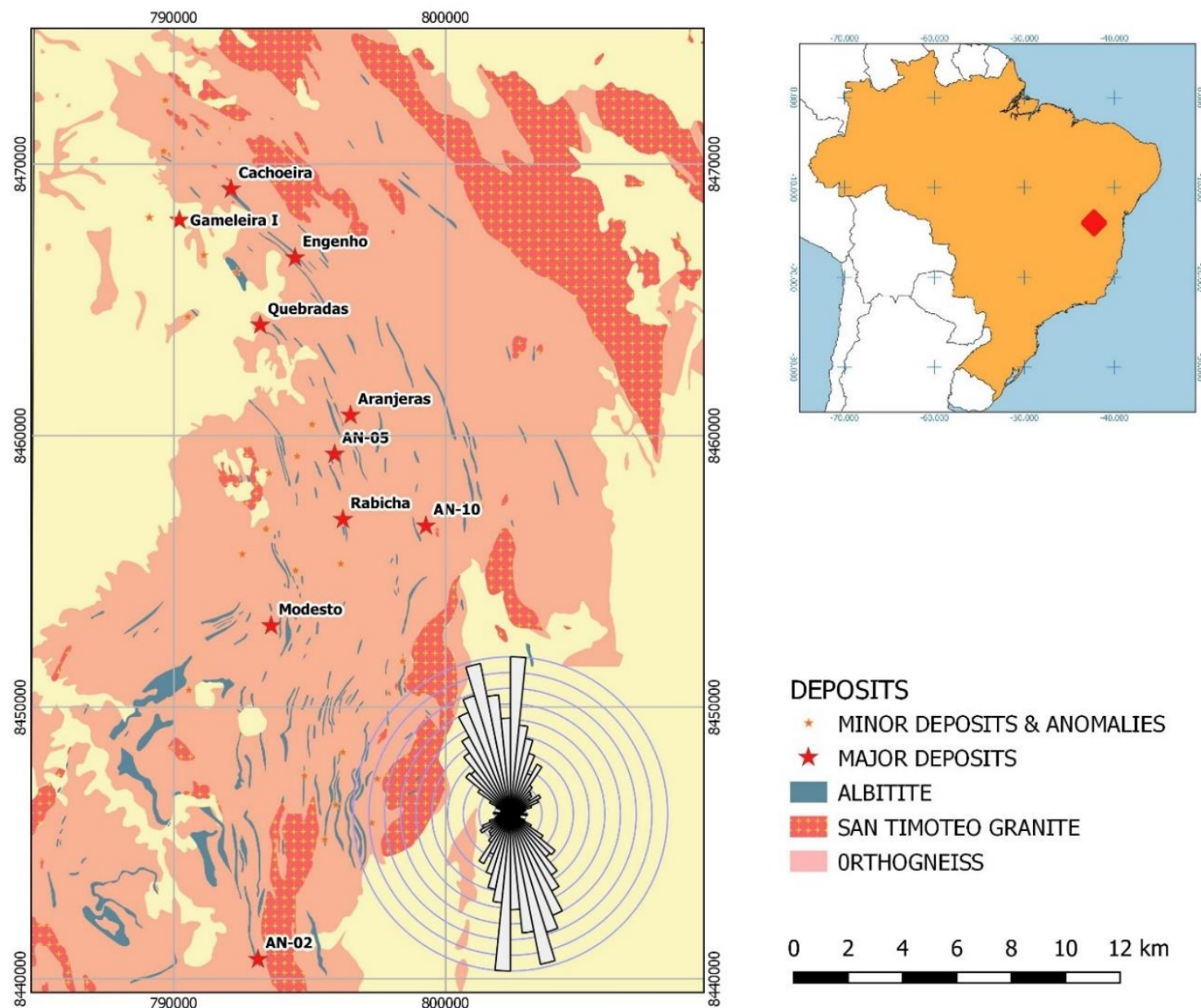

\section{DEPOSITS}

* MINOR DEPOSITS \& ANOMALIES

$\star$ MAJOR DEPOSITS

ALBITITE

W. SAN TIMOTEO GRANITE

ORTHOGNEISS

\section{\begin{tabular}{lllllll}
0 & 2 & 4 & 6 & 8 & 10 & 12 \\
\hline
\end{tabular}}

Figure 3. Simplified geology of the Lagoa Real district [9]. The rose diagram shows the trends of over 180 discrete albitite bodies. 


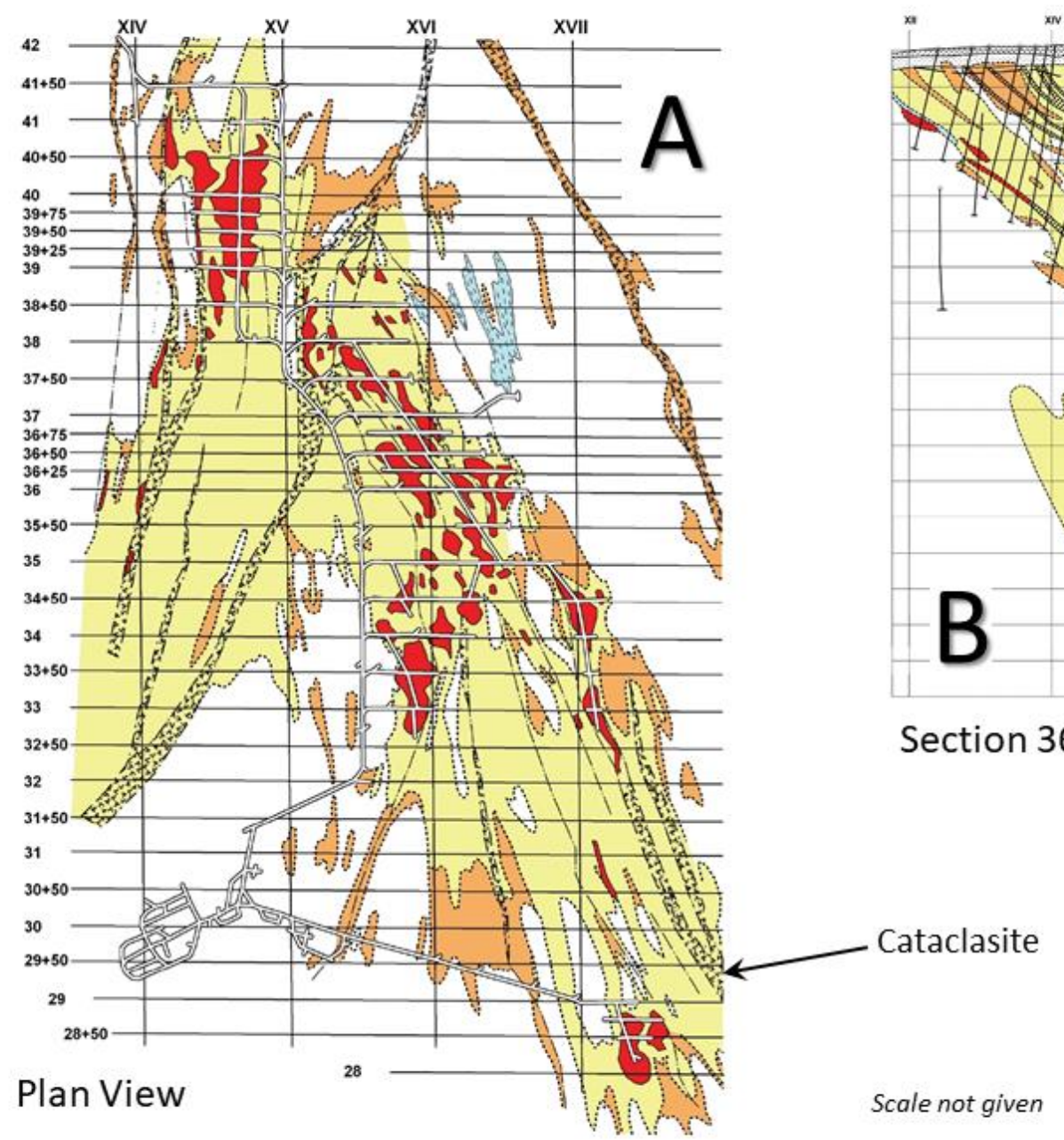

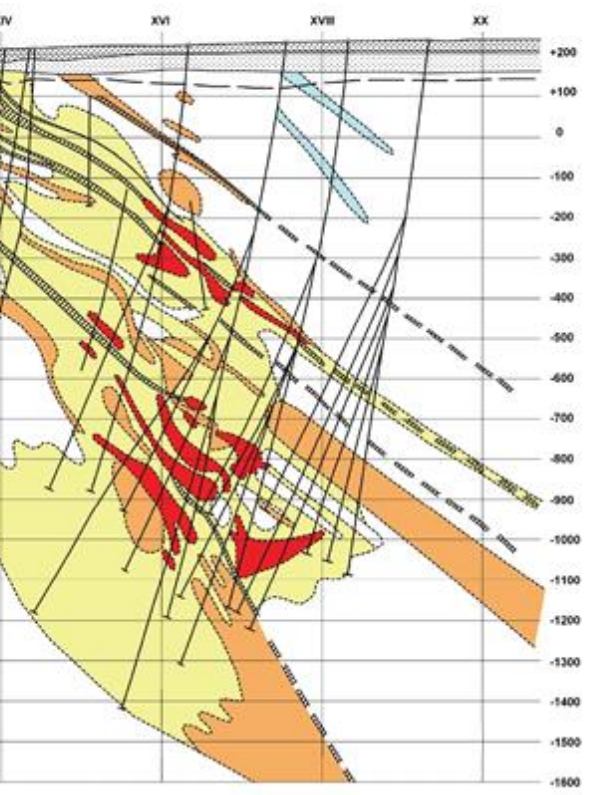

36

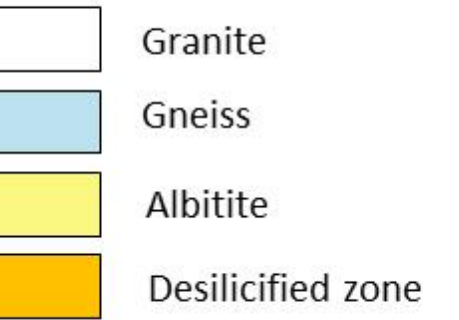

Figure 4. A-plan view of the Novokostantynivka deposit, Kropyvnytskyi district. B—section of the Novokostantynivka deposit, Kropyvnytskyi district. Source: Bararzhiyev. Cuney \& Emetz pers. comm. 


\section{Descriptive Geological Model}

\subsection{Structural Control and Host Rocks}

Shear-hosted uranium deposits are structurally controlled in steeply dipping mylonite zones developed in a range of host-rocks. Because of this control, the orebodies tend to be elongated along the plunge of the hosting shear zone (Figures 4 and 5). Host-rocks vary in age from Proterozoic to Phanerozoic. The most common host-rocks are granitoid, but many other lithologies are mineralised, including a wide variety of gneissic rocks, meta-basalt, meta-rhyolite, meta-siltstone and in the case of Zhovta Richta and Itataia, marble, all metamorphosed in the greenschist to granulite facies $[2,3,10]$. This lack of preference for a specific host-rock chemistry or mineralogy suggests that the chemical and mineralogical nature of the host-rock is at best a secondary factor in the localisation of economic mineralisation. Host rock composition may have a greater influence in dictating hydrothermal alteration mineralogy (see below).

While the host shear zones generally retain an early, high-temperature and ductile history, uranium introduction can be shown in most cases to be related to late brittle fracturing and brecciation $[2,3,11,12]$ (Figures 6 and 7). Shear zones are associated with intense, pervasive high-temperature sodic alteration paragenesis that includes abundant albitic feldspar (less commonly potassium feldspar) and often sodic amphibole (riebeckite) and sodic pyroxene (aegirine augite). Sodic alteration is preceded or accompanied by quartz dissolution, producing in some cases vuggy, porous rocks sometimes referred to as 'episyenite' $[2,13]$. Carbonate minerals (dolomite and calcite) predating uranium deposition may also be present in the early albitite assemblages at some deposits. Epidosites (i.e., rocks dominated by epidote) occur in marginal albitites at Lagoa Real [14] and are also recognised at Mount Isa although a link to uranium mineralisation is yet to be established here [15].

\subsection{Ore Mineral Assemblages}

The deposit group has diverse ore stage mineral assemblages and bulk mineralogy differs substantially between adjacent deposits in the same district and even within deposits since some deposits are zoned $[2,12,16,17]$. Deposition of uranium can typically be shown to postdate (i.e., to vein or replace) the relatively high-temperature, feldspar-dominant hydrothermal alteration assemblage, but in some instances uranium deposition appears to be coeval with riebeckite formation (e.g., Coles Hill, [18]). Ore mineral assemblages typically contain a high proportion of refractory phases such as brannerite, U-ferropseudobrookite and an unnamed uraniferous Zr-rich mineral [2,12]. Amorphous 'U-Ti-metagel' has been described in the Elkon deposits [7]. Uraninite and coffinite are generally present in varying proportions and volumes, as well as uranium occurring in the lattice of, or as inclusions in, titanite, rutile, ilmenite and magnetite. Other phases that have been described include an unidentified uranium silicate, thorite, fourmarierite and hawaiite.

Unusually high volumes of hydrothermal zircon and phosphates (apatite and fluorapatite) are commonly found in the deposits and this is a defining feature of the group. The Itataia (Santa Quiteria) deposit in Brazil contains 9 million tonnes of phosphatic 'collophanite' mineralisation (uraniferous fluorapatite). At the Zhovta Richta deposit in Ukraine, apatite makes up as much as $90 \%$ of the ore when the host rock is a 'meta-carbonate' [2]. Anderson's Lode (Mount Isa District) contains an average of $20 \%$ hydrothermal fluorapatite [19]. Fluorapatite at the Coles Hill deposit contains approximately $4 \%$ of the total uranium [20].

A few of the deposits are enriched in carbonaceous matter. A late breccia with uraniferous and carbonaceous material ('black ore') at Itataia contains the highest U grades in the deposit (Angeiras, 1988). Uranium in the black ore is associated with zircon and pyrite and is present as uraninite and coffinite (Calvalcanti et al., written communication). Carbonaceous matter is also present at the shear-zone hosted Zadni Chodov deposit in the Czech Republic [21]. The paragenetic relationship of the carbonaceous material to other stages is not well understood at present. 

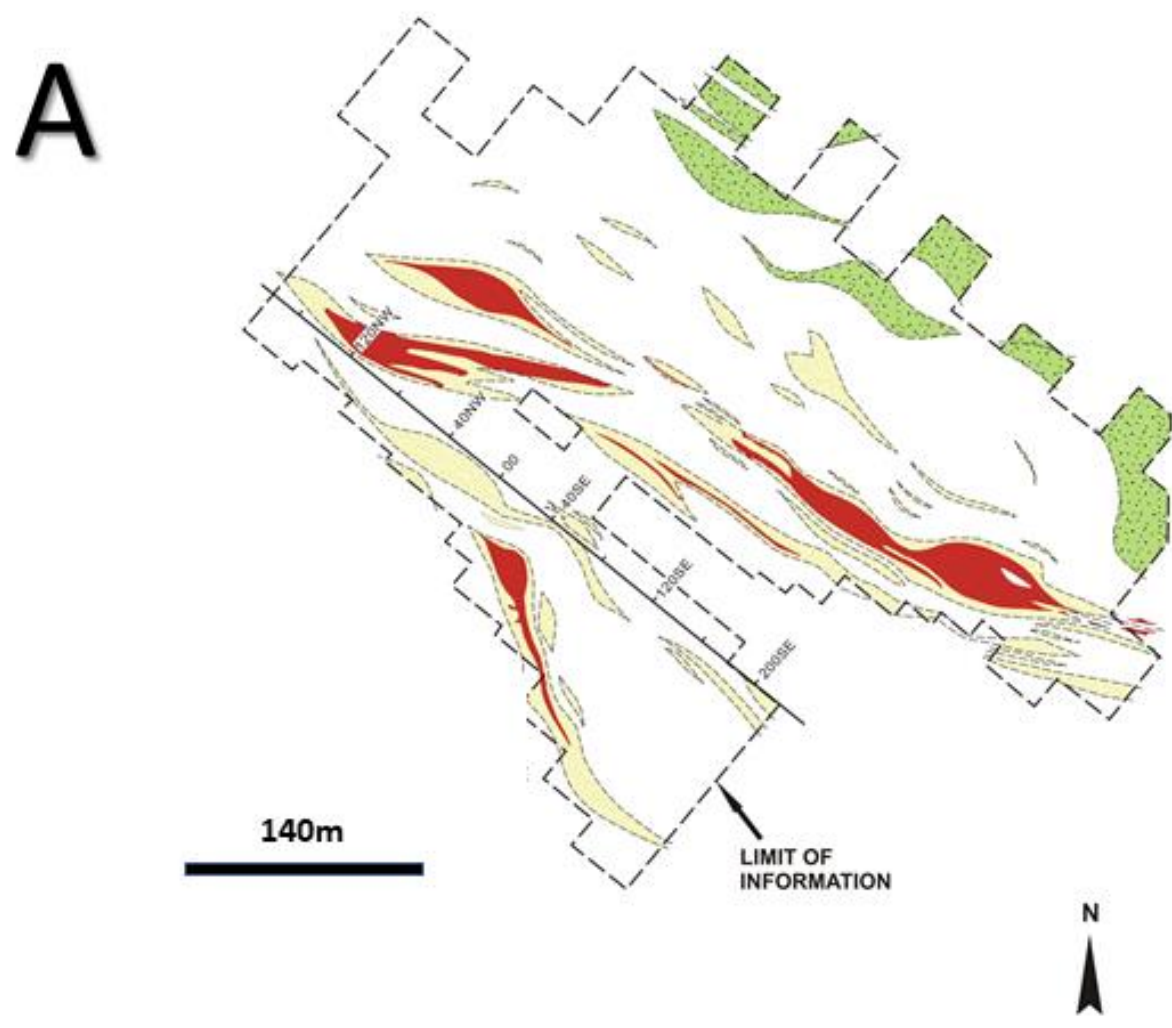

B

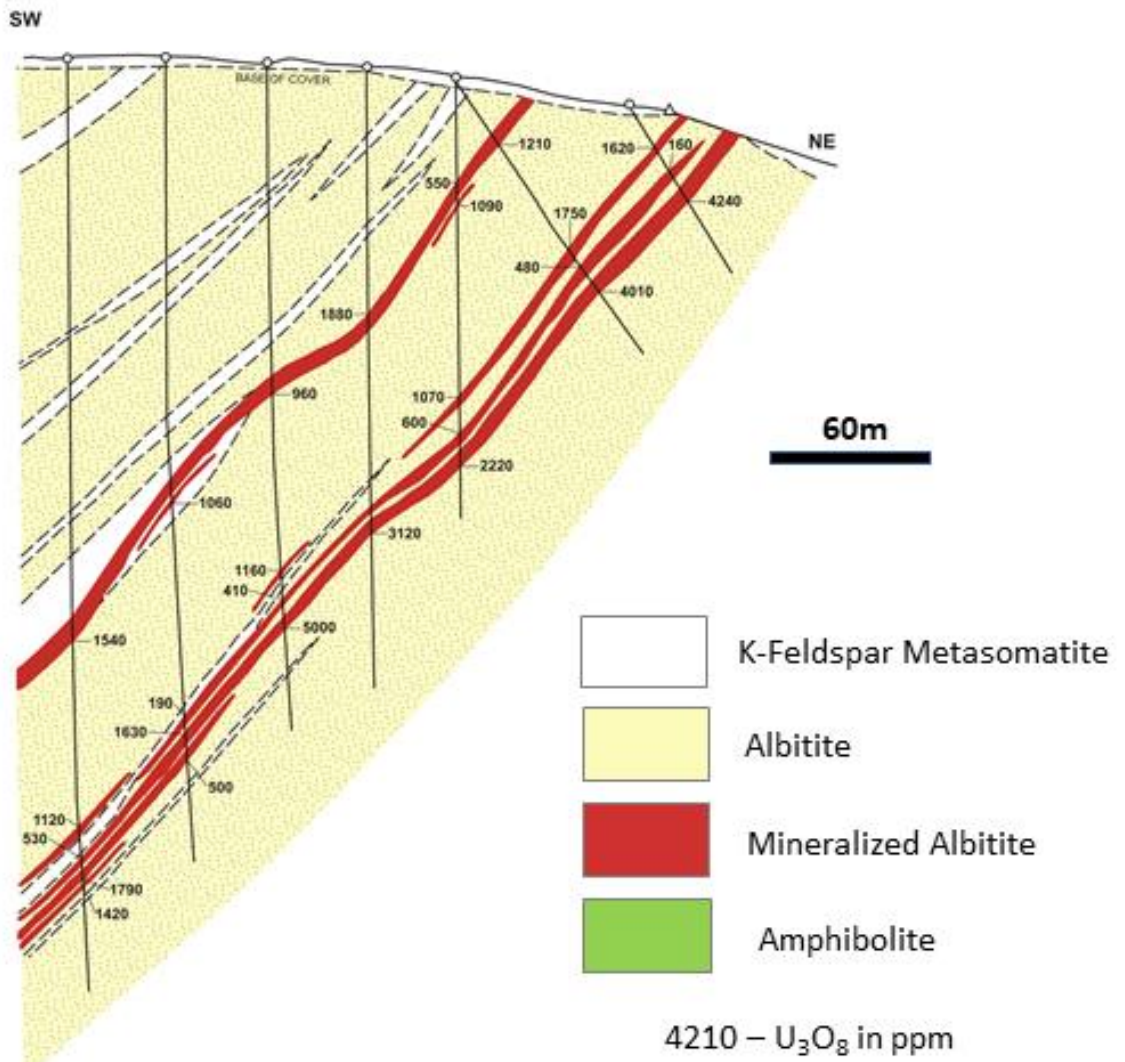

Figure 5. (A) — plan view of the Cachoeira deposit, Lagoa Real district. (B) — section from the Rabicha deposit, Lagoa Real District. From de Oliveira et al., 1985. 

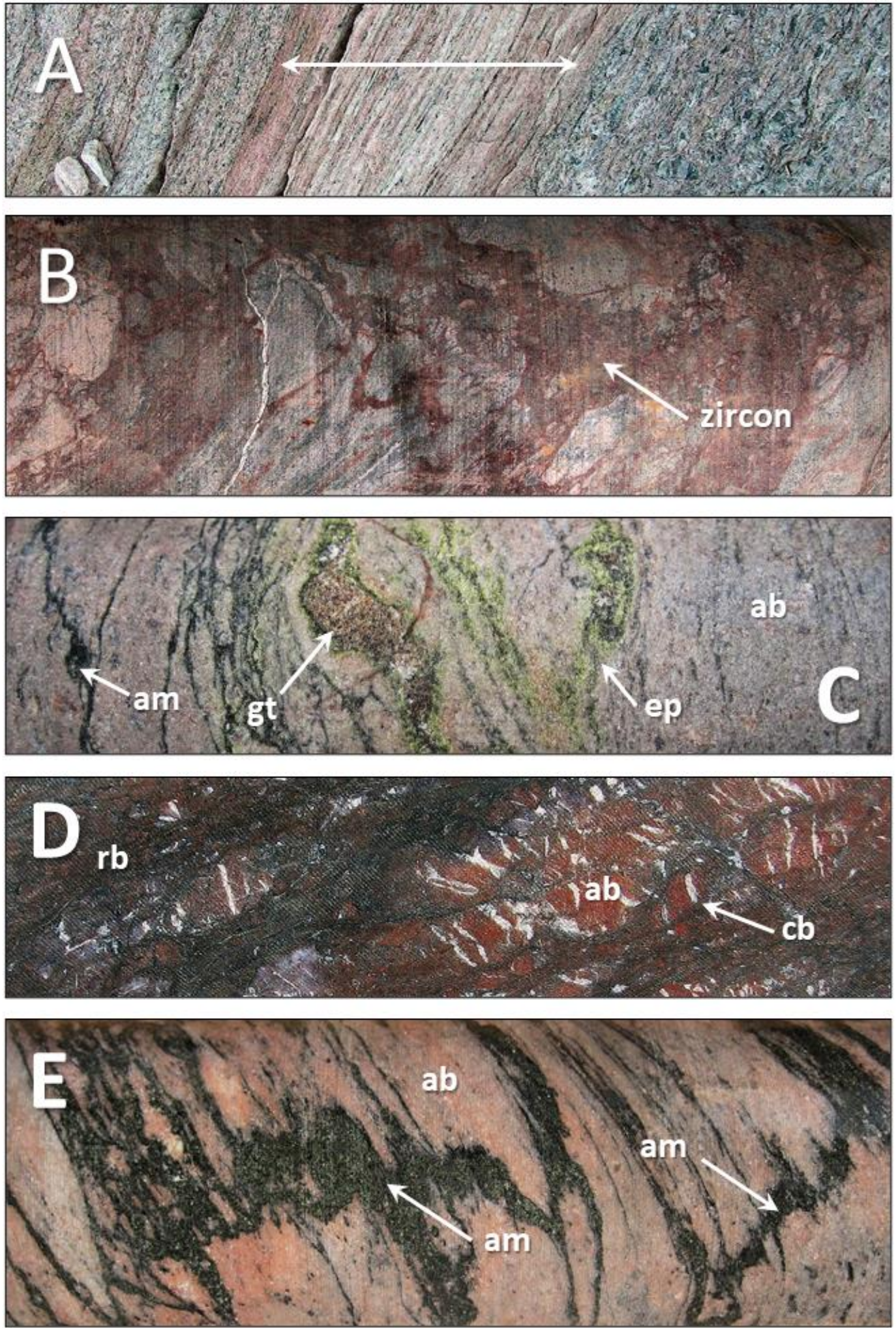

Figure 6. Photographs of core samples, field of view approximately $10 \mathrm{~cm}$. (A) —shear zone in felsic meta-volcanic rock, Michelin deposit, Central Mineral Belt. (B)-hydrothermal zircon cemented breccia, Valhalla, Mt Isa District. (C)-hydrothermal garnet (gt) and late epidote (ep) cutting albitite (ab), Michelin deposit. (D) - early albitite (ab) clasts in shear zone defined by lineated riebeckite ( $\mathrm{rb}$ ) and late carbonate veins (cb), Queen's Gift deposit, Mt Isa District. (E)—amphibole (am) veins cutting albitite (ab), Michelin deposit. 

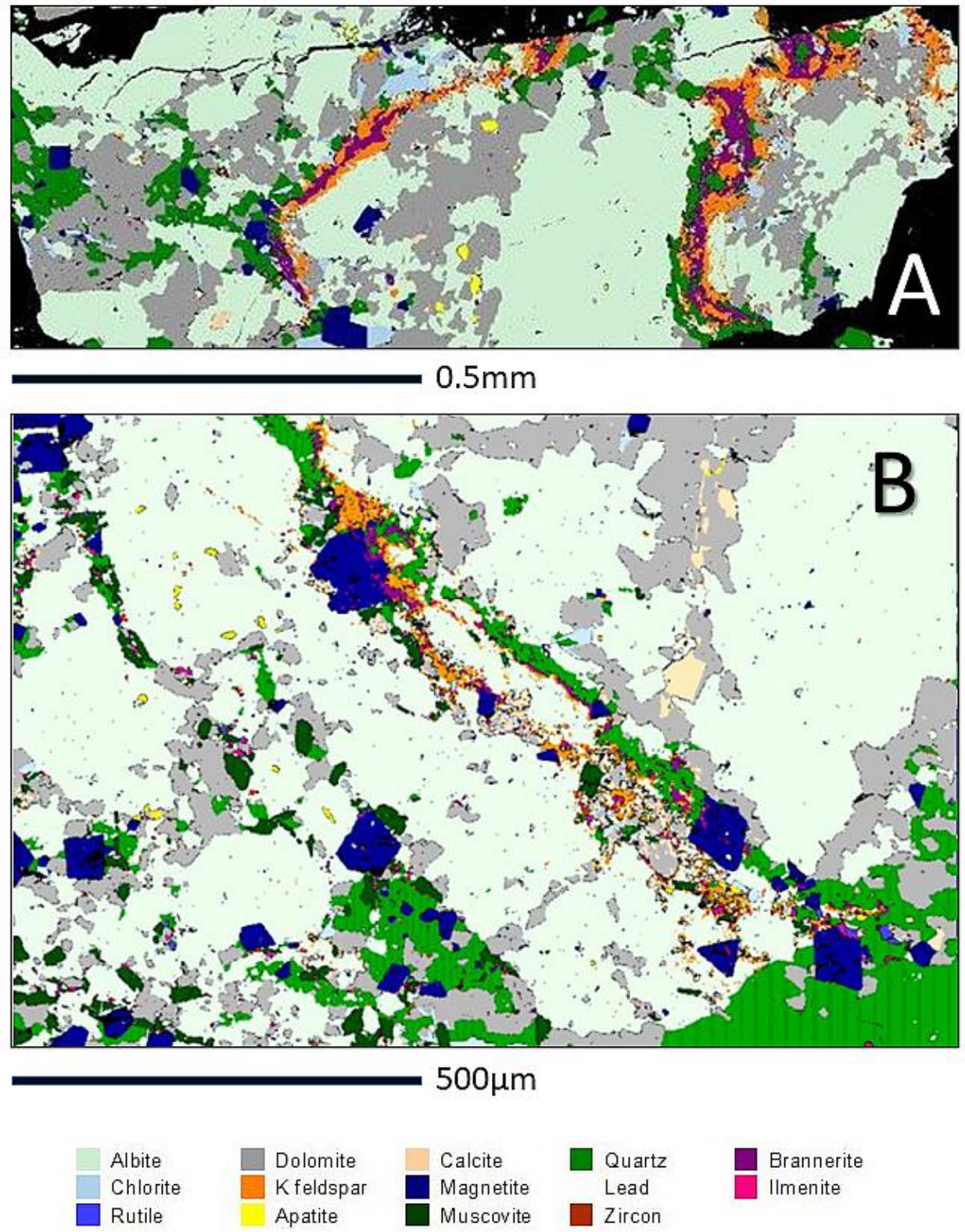

Figure 7. Mineral maps generated using hyperprobe showing brannerite-K-feldspar microveins in albitite. (A)—Skal deposit, Mt Isa. (B)—Valhalla deposit, Mt Isa [12].

\subsection{Hydrothermal Alteration Controlled by Brittle Structures}

Several hydrothermal alteration assemblages paragenetically related to uranium deposition overprint sodic alteration minerals and occur to varying extents in some of the deposits. The Ca-Mg stage defined by Cuney et al. [2] is based on deposits of the Kropyvnytskyi district and is manifested by combinations of andradite garnet, titanite, diopside, magnesio-riebeckite, epidote and carbonate minerals plus U-Ti minerals, uraninite, zircon and apatite (Figure 6). These minerals replace and fill veins and cement breccias in albitites. At Mount Isa, Polito et al. [22] documented zonation in early magnesio-riebeckite that indicates evolution towards a more Ca- and $\mathrm{Mg}$-rich and Na-poor composition, but garnet and diopside are uncommon and carbonate minerals often postdate uranium deposition [12].

Ca-Mg stage minerals at Kropyvnytskyi are overprinted by a potassic assemblage defined by biotite or phlogopite and calcite, with lesser volumes of K-feldspar [2]. Uranium minerals occurring with potassic phases are brannerite and uraninite. Pyrite is a common accessory phase ([2], Figure 7). 
The potassic stage is well developed at Mount Isa where much of the uranium occurs in association with biotite, K-feldspar and Ti and Fe oxides in microveinlets (e.g., [12]).

The latest phase recognised in the Kropyvnytskyi deposits consists of veinlets of chlorite, epidote and calcite with rare quartz, barite and coffinite [2]. Post-uranium calcite veins with associated epidote and chlorite alteration are common in samples of Mount Isa ore [12]. Late chlorite at Mount Isa can be related to late and unmineralized faults which offset the primary albitite bodies, and is also widely distributed in the host meta-basalts $[12,15]$. Chlorite and calcite are inferred to predate rather than postdate zircon and brannerite formation at Kurupung [13].

\section{Geodynamic Settings}

The Kropyvnytskyi district of Central Ukraine contains at least twenty-two shear-hosted deposits collectively containing over 327,000 tonnes of $\mathrm{U}_{3} \mathrm{O}_{8}$ (Table 1; Figure 2). The district is located within a $>500 \mathrm{~km}$ long north-south trending tract of Archean metasedimentary rocks (Ingul-Ingulets Series) intruded by two major batholith bodies, the 2.05 Ga Nouvokrainka batholith and $1.75 \mathrm{Ga}$ Korsun-Novomyrgorod Complex [2,23]. Peak regional compressive deformation and granulite-facies metamorphism are dated at approximately $1.81 \mathrm{Ga}$, which is within error of the age of intrusion of a suite of basaltic, high Mg (picrite) and kimberlite dykes (Shumylanskyy et al., 2015; pers. comm., 2018). These dykes are spatially related to the uranium deposits and are inferred to be the product of a mantle plume event (Shumylanskyy et al., 2015).

The 1.75 Ga post-compressional Rapakivi-type granite, gabbro and anorthosite intrusions of the Korsun-Novomyrgorod Complex form a batholithic body of $55,000 \mathrm{~km}^{2}$. The complex is interpreted to be a product of crustal melting induced by introduction of mantle-derived mafic melts that gave rise to picrites and kimberlites [23].

Albitites occur within the Nouvokrainka but not the Korsun-Novomyrgorod batholith, suggesting to Shumylanskyy et al. [24] that the albitites formed prior to $1.75 \mathrm{Ga}$. Direct dating of albitites and contained uranium mineralisation yields a wide range of ages between 1.86 and $1.74 \mathrm{Ga}$, [24-26]. Thus, the Kropyvnytskyi deposits overlap peak compression and metamorphism but predate intrusion of the post-tectonic Korsun-Novomyrgorod Complex [2,24].

Deposits of the Lagoa Real district are located within the Proterozoic Lagoa Real Granitic-Gneissic Complex which forms part of the Araçuai Orogen [27]. The complex consists of granitic gneiss and amphibolite in addition to the ca. 1.74 Ga porphyritic San Timoteo intrusion (granite, syenogranite and syenite [27-29]. The district contains over 180 albitite occurrences, at least ten uranium deposits and over 20 occurrences ([27], Figure 3). The absolute age (or ages) of uranium mineralisation at Lagoa Real is poorly defined and primary ages range from 1.94 to $0.82 \mathrm{Ga}[27,29,30]$. It is likely that this range in primary 'ages' reflects mobility of $\mathrm{U}$ and/or radiogenic $\mathrm{Pb}$. Without a definitive age for uranium emplacement, the geodynamic setting of uranium deposit formation at Lagoa Real cannot be confidently defined.

The Mount Isa uranium district of Queensland, Australia, contains seventeen shear-hosted uranium deposits. It is situated within an extensive Proterozoic terrane well-known for its endowment of giant sedex-type $\mathrm{Pb}-\mathrm{Zn}$, Mt Isa-type $\mathrm{Cu}$ and large IOCG deposits such as Ernest Henry and Mount Elliot. The host-rocks to the less well-known shear-hosted uranium deposits are greenschist to amphibolite facies meta-basalt and meta-siltstone of the ca. $1.83 \mathrm{Ga}$ Eastern Creek Volcanics [31]. The main regional compression event, $\mathrm{D}_{2}$, imparted a pervasive foliation and north-south structural trend at between 1.59 and $1.55 \mathrm{Ga}$ [32]. Albitite bodies that host uranium mineralisation appear slightly discordant to the prominent $S_{2}$ foliation $[12,33]$. This may indicate that shearing postdated formation of the foliation, or that the albitised shear zones were reoriented into the plane of the foliation during progressive deformation.

The absolute age of uranium emplacement at Mount Isa is not well defined, with only two samples from the Valhalla deposit dated [22]. These Valhalla samples yielded a U-Pb brannerite age of $1.56 \pm 0.03 \mathrm{Ga}$, indicative of formation during the Isan compressive orogeny [22]. Three episodes of 
regional albitisation have been documented in the Mount Isa region [34,35] but the albitite hosting uranium has not been dated. The earliest episode of regional albitisation is contemporaneous with mafic dyking and intrusion of a major granitic batholith (Sybella Batholith) at 1.69-1.63 Ga [34-36]. The second is synchronous with peak compressive deformation at $1.59-1.57 \mathrm{Ga}$, and a third post-dated peak deformation at 1.55-1.50 Ga [34-36].

The Mount Isa deposits show no obvious spatial association with outcropping intrusions such as the $1.66 \mathrm{Ga}$ Sybella Batholith and apparently predate the intrusion of a suite of 1.55 and $1.50 \mathrm{Ga}$ granitic intrusions that are implicated in the formation of major IOCG deposits such as Ernest Henry and Mount Elliot [35]. At Ernest Henry, an early paragenetic 'remnant' of albitised metavolcanic rocks has recently been reported, in association with hydrothermal apatite and dated at approximately $1.59 \pm 0.03 \mathrm{Ga}$ [37]. The main copper deposition is, however, dated at ca. $1.53 \mathrm{Ga}$ [37].

The Central Mineral Belt (CMB) of Central Labrador contains eleven substantial uranium deposits of which the Michelin deposit is the largest (Tables 1 and 2). The CMB incorporates a triangular wedge-shaped block of mainly Proterozoic amphibolite-facies metamorphic and intrusive rocks which includes the Makkovik Province, as well as portions of the Nain, Churchill and Grenville Provinces. Besides the numerous uranium prospects, a substantial number of copper and molybdenum occurrences have also been documented throughout the CMB [38].

Most significant uranium deposits, including Michelin, Jacques Lake and Rainbow, are hosted within the ca. $1.86 \mathrm{Ga}$ Aillik Group metavolcanic rocks [39,40]. Peak $\mathrm{D}_{3}$ deformation of the Makkovikian Orogeny is dated at between 1.81 and $1.79 \mathrm{Ga}$ and involved westward thrusting of the Aillik Group with concomitant development of steeply dipping shear zones and development of pervasive foliation [38,41]. The age of mineralisation at Michelin has been bracketed at between $1.86 \mathrm{Ga}$, the age of the Aillik metavolcanic host rocks, and $1.80 \mathrm{Ga}$, the age of a supposedly post-mineralisation dyke [42]. This implies uranium deposition at Michelin overlapped Makkovikian compression. Direct dating of several other $\mathrm{CMB}$ deposits, however, revealed a pooled $\mathrm{U}-\mathrm{Pb}$ age of $1.74 \pm 0.02 \mathrm{Ga}$, substantially postdating peak deformation and consistent with regional Ar-Ar ages of 1.72-1.73 Ga [43,44]. Further research is needed to resolve this apparent contradiction, but the conflicting ages could perhaps be indicative of more than one mineralising event.

\section{Hydrothermal Fluids, Ligands and Metals}

Several authors have proposed that uranium in shear-hosted deposits is derived from granitoid rocks that host the deposits or which occur close by $[45,46]$. Evidence in support of this hypothesis comes from shear zones within the Sybella Batholith at Mount Isa which display evidence of removal of both $\mathrm{U}$ and $\mathrm{F}$ synchronous with ore formation at Valhalla [22,45,47]. It should be noted that the Sybella batholith is the most radiometrically anomalous (and hence uranium-rich) of many intrusive bodies in the Mount Isa region. The nearby major Mary Kathleen deposit although not shear hosted is also associated with an anomalously radiogenic intrusion, supporting the notion that the association is not a coincidence.

The uranium content of granitic intrusions of Lagoa Real and Kropyvnytskyi is unfortunately not well documented. Chaves et al. [30] proposed that uraniferous titanite in the host granitoid rocks was the source of uranium in mineralised albitites at Lagoa Real, implying that the ultimate source of uranium was magmatic, possibly the San Timoteo intrusion. Metamorphic rocks have also been suggested as a uranium source $[1,46]$ but granitoid rocks remain the most plausible.

Various hydrothermal fluid sources have been postulated, based to a large extent on stable isotopic data. Early studies proposed that the source of hydrothermal fluids was metamorphism, i.e., water produced during dehydration reactions (e.g., [1]). Stable isotope data are consistent with early-stage alteration being produced by circulation of meteoric ('surficial') or basinal waters to considerable depths $[2,13,22,46,48]$. Polito et al. [22], however, acknowledged that oxygen and hydrogen stable isotope data from Valhalla were equivocal and could not distinguish between basinal or magmatic origin, while Alexandre [13] inferred that fluid in equilibrium with ore-stage zircon 
at the Aricheng deposit was magmatic in origin, or, alternatively 'fully equilibrated with granitoid host-rocks'. Carbon isotopic data from Kropyvnytskyi were interpreted to indicate two sources of carbon, one with $\delta^{13} \mathrm{C}$ close to 0 and derived from seawater or from carbonate lithologies. The second source had very low $\delta^{13} \mathrm{C}$ derived from organic-rich metamorphic host-rocks or from sediments within an overlying basin [2].

A significant impediment to fluid inclusion study of the ore-forming fluids has been the absence of quartz, necessitating consideration of minerals that are less suitable for this type of study (Table 3). Various fluid inclusion studies have revealed a range of homogenisation temperatures at different deposits (Table 3). It is not clear in most cases how this range relates to trapping temperature. Few studies appear to have investigated the possibility of post entrapment volume changes and gain or loss of inclusion contents $[49,50]$. Furthermore, few studies appear able to reliably assign primary versus secondary or pseudosecondary origin. Nevertheless, fluid inclusions in minerals of all paragenetic stages are consistently saline (5-20 wt $\% \mathrm{NaCl}$ equiv.) indicating that the hydrothermal fluids were likely to have included brines irrespective of whether they are related to early albitisation or later alteration and mineralisation (Table 3). $\mathrm{CO}_{2}$ activity was probably high during mineralisation based on the abundance of carbonate minerals. This assertion is only partially supported by fluid inclusion data since fluid inclusions from Lagoa Real apparently lack a significant gas component that can be related to uranium precipitation $[9,51]$.

Table 3. Compilation of summary fluid inclusion data for shear-hosted uranium deposits.

\begin{tabular}{|c|c|c|c|c|c|c|}
\hline Deposit. & Mineral & $\begin{array}{l}\text { Primary or } \\
\text { Secondary }\end{array}$ & $\mathrm{T}_{\mathrm{h}}$ & $\begin{array}{c}\text { Salinity } \\
(\% \mathrm{NaCl} \text { eq })\end{array}$ & $\begin{array}{c}\% \\
\text { Vapour }\end{array}$ & Source \\
\hline \multicolumn{7}{|l|}{ KROPYVNYTSKYI } \\
\hline \multirow[t]{5}{*}{ Novokonstantinivka } & Albite & Primary & $>350$ & - & $10-30$ & {$[2,25]$} \\
\hline & Quartz & Primary & $>295$ & $16-19$ & $30-40$ & {$[2,25]$} \\
\hline & Calcite & $\begin{array}{l}\text { Primary and } \\
\text { Secondary }\end{array}$ & 131-198 & $14-21$ & $4-7$ & {$[2,25]$} \\
\hline & Andradite & Secondary & $122-189$ & $6-12$ & $3-35$ & {$[2,25]$} \\
\hline & Quartz & Secondary & $110-210$ & $5-11$ & $4-8$ & {$[2,25]$} \\
\hline \multirow[t]{3}{*}{ Pershotravneve } & Quartz & - & $140-220$ & - & - & {$[52]$} \\
\hline & Aegirine & - & $>210$ & - & - & [52] \\
\hline & Carbonate & - & 195-255 & - & - & [52] \\
\hline \multirow[t]{2}{*}{ Severynka } & Ankerite & Primary & $237-252$ & - & - & [53] \\
\hline & Calcite & Primary & $70-165$ & - & - & [53] \\
\hline Zhovta Richka & Albite/Quartz & Primary? & $250-380$ & - & 30 & [52] \\
\hline \multicolumn{7}{|l|}{ LAGOA REAL } \\
\hline \multirow[t]{4}{*}{ Engenho } & $\begin{array}{c}\text { Pyroxene, garnet, } \\
\text { epidote }\end{array}$ & - & nd & 14-18 & none & [50] \\
\hline & Garnet & - & $200-230$ & 12 & & [9] \\
\hline & Albite & - & nd & $<14$ & none & [50] \\
\hline & Albite & - & $200-320$ & 3 & & [9] \\
\hline Cachoeira & Garnet & - & - & 15 & & [9] \\
\hline \multirow[t]{2}{*}{ Rabicha } & Garnet & - & $200-240$ & 12 & & [9] \\
\hline & Albite & - & $223-383$ & 3 & & [9] \\
\hline \multicolumn{7}{|l|}{ OTHER } \\
\hline \multirow[t]{2}{*}{$\begin{array}{c}\text { Jiling and } \\
\text { Xinshuijing }\end{array}$} & Calcite & Syn-uranium & $70-228$ & $1-15$ & - & [46] \\
\hline & Calcite & Post-uranium & $97-232$ & $0-6$ & - & [46] \\
\hline
\end{tabular}


The coexistence of sodic pyroxene and amphibole in the early albitites is indicative of relatively high temperatures of formation during albitite formation and possibly during the early stages of uranium mineralisation. Cuney et al. [2] estimated a minimum of $450{ }^{\circ} \mathrm{C}$ for albitite formation at Kropyvnytskyi, based on riebeckite geothermometry and the temperature required for ductile deformation of albite. This estimate is consistent with an estimate of $500-550{ }^{\circ} \mathrm{C}$ peak temperatures at Lagoa Real based on stable isotope geothermometry and implies formation at a depth of approximately $10 \mathrm{~km}$ assuming an elevated geothermal gradient of $50^{\circ} \mathrm{C} / \mathrm{km}[2,14]$. Fluid inclusion homogenisation data and chlorite geothermometry suggest that the formation of albite-carbonate alteration at the Kurupung deposit (Guyana) occurred between 380 and $210^{\circ} \mathrm{C}$ [54]. This is a much lower range than inferred for Kropyvnytskyi and Lagoa Real but may explain the absence of riebeckite and aegirine at Kurupung.

Stable isotopic fractionation between riebeckite and calcite at the Valhalla deposit indicates formation between 380 and $340{ }^{\circ} \mathrm{C}$ [22]. By analogy with modern geothermal systems, Cuney et al. [2] proposed garnet formation at Kropyvnytskyi at a temperature of between 300 and $360^{\circ} \mathrm{C}$. Fluid inclusion data at Kropyvnytskyi were interpreted to indicate cooling to below $210^{\circ} \mathrm{C}$ of the mineralising system during the latter stages [2].

It would appear on the basis of these studies that mineralisation and related alteration occurred over a wide range of temperature from as much as $550{ }^{\circ} \mathrm{C}$ to as low as $200^{\circ} \mathrm{C}$.

Uranium-bearing fluids were likely to have been rich in fluorine as evidenced by elevated $\mathrm{F}$ in syn-ore amphibole and fluorapatite $[3,18,19]$. The abundance of fluorapatite also suggests that the activity of aqueous phosphorous was high [18]. High F activity can explain several features of the deposits, namely dissolution of quartz during early stage alteration and the cotransport of $\mathrm{U}$ and $\mathrm{Zr}$.

\section{Fluid Pathways}

The main fluid pathways for uraniferous hydrothermal fluids are likely to have been the shear zones that host the ore $[2,3,12,48]$. Deposits of the Ukraine are hosted by second-order north-south trending shears (faults) adjacent to major structures tapping deep into the crust, thus providing a potential channel for mantle-derived fluids [2]. The location of the Kropyvnytskyi orebodies is considered to have been localised by the intersection of these second-order shears with a set of NW-SE trending faults [2].

Structures that host uranium at Mount Isa are a series of north-south trending shears that transgress the pervasive regional foliation [12,33]. The shear zones are typically a few tens of meters wide, and where displacement can be demonstrated (which is uncommon), it is less than a few hundred metres. It is unlikely that these structures are of crustal extent but could perhaps be splays off such major structures. The deposits are clearly offset by NW-SE structures [12] but there is no evidence that the intersection of the two sets of structures localised ore. On the contrary, it seems that the offsetting structures are much later than mineralisation.

The Michelin deposit is hosted within mylonitised felsic metavolcanic rocks. The mylonite zone is slightly discordant to the regional foliation and to bedding defined by alternating coarse and fine-grained units within the host sequence, thus mirroring the spatial relationship between uranium-bearing structures and their host rocks seen at Mount Isa. It has not yet proved possible to determine the displacement direction and magnitude of this structure. As at Mt Isa, there is no evidence that later, cross-cutting structures have played a part in localising ore distribution. Rather, the distinct plunge of the mineralised body at Michelin can be explained by the intersection of the steeply dipping host shear zone and steeply dipping stratigraphic units [12].

\section{Drivers of Fluid Flow}

Although the geodynamic setting of uranium mineralisation remains uncertain in detail, common features appear to be that mineralisation overlaps compressive deformation and is not spatially, temporally or genetically related to granitic (sl) intrusion. These key points and the fact that the 
deposits are so closely related to shear zones permit the hypothesis that fluid flow is driven by broad thermal or mechanical gradients established during compressive deformation and regional low to medium grade metamorphism. Fluids equilibrated with metamorphic basement rocks would have been channelled upwards along shear zones similar to the scenario envisaged for orogenic gold deposits $[1,55,56]$.

An alternative model speculates that large-scale listric thrusting provided critical fluid pathways at Lagoa Real [14]. In this scenario, gneissic metamorphic rocks were thrust over sediments (Espinhaço Sediments) promoting compaction and dewatering of the sedimentary rocks. The result, was expulsion of quartz-undersaturated, sodic and relatively oxidised pore waters along steeply dipping portions of listric ductile shear zones in the upper plate gneisses [14]. There is no evidence that supports this model in the other three districts. While thrust faults have been documented in the Central Mineral Belt [41] recognition of thrusting at Mount Isa remains controversial [57]. Neither terrane possessed an unmetamorphosed sedimentary sequence that could have been dewatered at the time of Isan or Makkovikian deformation.

A third model was proposed for the Kropyvnytskyi deposits which incorporates some aspects of genetic models for the formation of unconformity-type uranium deposits ([2] see also Bruce et al., this volume). In this model, an overlying unmetamorphosed sedimentary basin supplied oxidised brines that flowed downwards into basement rocks along shears (faults) causing albitisation, while mixing with a second, upwards moving reduced fluid (of uncertain origin) caused uranium precipitation [2]. There are no vestiges of a sedimentary basin of suitable age overlying the Kropyvnytskyi deposits, but it could plausibly have been completely eroded given the long-lived and stable nature of the Ukrainian craton.

The fluid flow drivers in the third model were not explicitly discussed but it was assumed that the flow could be attributed to extensional tectonics. Indeed, modelling of fluid flow along permeable and porous faults through a sedimentary basin and into and out of underlying impermeable basement shows that basin-derived fluids are able to move many kilometres downwards into the basement rocks along faults, due to the development of underpressure in fault zones below the unconformity $[58,59]$. A key problem with this model, besides absence of any evidence of a superimposed basin, is the absence of any evidence of extension between 1.86 and $1.74 \mathrm{Ga}$.

Thermal convection could also explain localised downwards movement of oxidised brine through a superposed basin in the absence of any tectonic activity, if basin thickness, permeability, porosity and basal heat flow exceeded suitable thresholds $[58,59]$. Convective cells are unlikely to penetrate into relatively impermeable metamorphic basement rocks, however, until compaction and diagenesis substantially reduced the permeability of the basin rocks, equalising the permeability and porosity of basin and metamorphic basement [58]. Thermal convection alone does not explain the relationship between uranium deposits and shear zones.

\section{Depositional Processes}

Abrupt temperature decrease was inferred to have been the main factor in ore precipitation at Lagoa Real and was also proposed for Elkon [7,14]. Drop in hydrothermal fluid temperature would explain the change from paragenetically early pyroxene and amphibole to later chlorite and epidote observed in both of these deposits. Since high $\mathrm{CO}_{2}$ fugacity of ore-forming fluids is implied by the abundance of carbonate minerals, another possible depositional mechanism is a drop in aqueous $\mathrm{CO}_{2}$ activity resulting from the evolution of a $\mathrm{CO}_{2}$-rich gas phase. This may be the result of pressure fluctuations, and/or carbonate mineral formation, perhaps as upward moving fluid encountered zones of intense fracturing. Violent phase separation ('boiling') is not likely to be important in shear-hosted deposits, however, owing to the lack of indicative mineral textures, and likely formation at substantial depth and therefore confining pressure.

There appears to be no chemical or mineralogical feature of the host-rocks that is suggestive of protolith chemical control on uranium precipitation. The $\mathrm{K}$ and $\mathrm{Ca}-\mathrm{Mg}$ mineralisation types 
typically occupy veinlets in albitite and replace pre-existing sodic phases such as riebeckite, magnetite, ilmenite and aegirine. Thus, direct reduction of oxidised uraniferous fluids by $\mathrm{Fe}^{2+}$ in the albitites may be a potent depositional mechanism [2]. At Lagoa Real, increasing uranium content of the ores has been shown to correlate with $\mathrm{Fe}^{3+} / \mathrm{Fe}_{\text {tot }}$, supporting this concept [14]. This mechanism is implausible at Kropyvnytskyi, however, since uranium content correlates with decreasing rather than increasing $\mathrm{Fe}^{3+} / \mathrm{Fe}_{\text {tot }}$ [2]. To explain this observation, it has been proposed that uranium deposition was the result of mixing of oxidised basinal fluid with a reduced metamorphic fluid [2].

\section{Discussion}

\subsection{What's In a Name? Shear-Hosted vs. Albitite vs. Metasomatite}

The four major uranium districts of Kropyvnytskyi (Ukraine), Lagoa Real (Brazil), Mount Isa (Australia) and the Central Mineral Belt (Canada) contain sixty individual uranium deposits hosted within planar shear (ductile deformation) zones. Superimposed cataclasis and brecciation suggest multiple deformations or progressive deformation under declining pressure, temperature and depth. The polyphase shear zones are extensively feldspar-metasomatised which lead to the term 'metasomatite-type' being applied to this group of deposits [4] but this is a rather vague term and the definition includes some deposits that are not related to shear zones. The term 'albitite-type' has also been widely applied to the group but may not be appropriate given the consistent paragenetic relationship between uranium and potassic or calcic phases. Thus, it is proposed that the term 'shear-hosted' be adopted for the group. This term has previously been applied to deposits of the Bohemian district of the Czech Republic [21,60] and it is logical that this term be extended to the group of deposits described herein.

\subsection{Mineral System Model}

Shear zones are widely acknowledged to be major conduits of fluid during compressive deformation (e.g., [55,56]). Although the absolute age of uranium mineralisation remains imprecise and uncertain, it is likely that formation of shear-hosted uranium deposits in at least three of the four major districts discussed above overlapped major compressive deformation events at between 2.1 and $1.8 \mathrm{Ga}$. Regional albitisation occurred synchronously with ductile deformation (mylonitisation) while uranium was introduced later under conditions close to the brittle-ductile transition. The transition from ductile to brittle/ductile deformation is consistent with progressive deformation under a declining temperature regime as indicated by the hydrothermal alteration assemblages and other data. An alternative explanation developed in the Kropyvnytskyi region is that secondary fracturing and hence localisation of uranium mineralisation deposits is the result of later cross-cutting structures [1,2]. This implies that albitites are more susceptible to fracturing than adjacent host-rocks [1]. No evidence for the control of uranium mineralisation by cross-cutting structures has been advanced at Mount Isa, Lagoa Real and the Central Mineral Belt. Conversely, cross-cutting structures at Mount Isa offset and postdate mineralisation and are unlikely to have triggered ore formation [3].

Fluid inclusion data cited above suggest that the fluids involved in uranium mineralisation were highly saline. Salinity could have been derived from evaporative conditions in an overlying unmetamorphosed basin as previously postulated [2]. Alternatively, the salinity could have been derived from within the metamorphic rock package. The Mount Isa terrane contains convincing evidence for the former presence of evaporitic sediments now represented mainly by scapolite. Such scapolite-rich rocks are likely to give rise to oxidised and Cl-rich (and possibly P-and F-rich) fluids during metamorphism [61].

Aqueous uranium-sodium-carbonate and phosphate complexes have been proposed to explain transport of uranium into albitite-type deposits. The association of uranium with HFSE and dissolution of Si from host-rocks, however, can be rationalised as the product of F-rich fluid. Therefore, uranium may have been introduced as a complex with $\mathrm{F}$ rather than, or as well as, $\mathrm{Cl}^{-}, \mathrm{PO}_{4}$ or $\mathrm{CO}_{2}$. But the nature of 
the ore-bearing fluids remains poorly defined, consequently depositional mechanisms are likewise ill-defined. The diversity of ore and gangue minerals may indicate that host-rock chemistry exerts a major role on alteration mineralogy even though there is no evidence that host-rock composition was critical in uranium deposition.

\section{Conclusions}

Uranium deposits previously categorised as metasomatite- or albitite-type have been grouped into a shear-hosted category, a term previously used to describe some deposits of the Bohemia district of the Czech Republic. Over 100 examples of this deposit type are known, located on all continents, accounting for as much uranium as the better known and higher-grade unconformity-type deposits.

Reasonably well understood aspects of the deposits include structural setting, gangue mineralogy and bulk chemistry. The fine-grained nature of the uranium minerals, however, requires further research using tools capable of sub-micron spatial resolution. Perhaps the biggest unknowns are the nature of the ore-forming fluids and depositional mechanisms and the ultimate driving force for mineralisation. In order to better understand these parameters, more work is required to constrain the physio-chemical conditions of ore-bearing fluids (by means of, for example, in-situ ICP-MS of fluid inclusions), as well as the spatial and temporal relationships between mineralisation, structural processes and far-field events.

Funding: This research received no external funding.

Acknowledgments: I thank Frank Bierlein for thoroughly reviewing an early version of the manuscript. Constructive reviews by two anonymous reviewers greatly improved the finished product.

Conflicts of Interest: The author declares no conflict of interest.

\section{References}

1. Belevtsev, Y. Endogenic uranium deposits of Precambrian shields: Environment of deposition. In Albitized Uranium Deposits: Six Articles Translated from Russian Literature; Abou-Zied, S., Kerns, G., Eds.; U.S. Department of Energy: Washington, DC, USA, 1980; pp. 55-80.

2. Cuney, M.; Emetz, A.; Mercadier, J.; Mykchaylov, V.; Shunko, V.; Yuslenko, A. Uranium deposits associated with Na-metasomatism from central Ukraine: A review of some of the major deposits and genetic constraints. Ore Geol. Rev. 2012, 44, 82-106. [CrossRef]

3. Wilde, A. Towards a model for Albitite-type uranium. Minerals 2013, 3, 36-48. [CrossRef]

4. International Atomic Energy Agency. Geological Classification of Uranium Deposits and Description of Selected Examples; International Atomic Energy Agency: Vienna, Austria, 2018; p. 430.

5. Wyborn, L.; Heinrich, C.; Jacques, L. Australian proterozoic mineral systems: Essential ingredients and mappable criteria. In Proceedings of the AusIMM Annual Conference: Darwin, Victoria, Australia, 5-9 August 1994; pp. 109-115.

6. Industrias Nucleares do Brasil. 2020. Available online: https://www.inb.gov.br/en-us/INB/Where-we-are/ Santa-Quiteria (accessed on 1 May 2020).

7. Komarova, M.M.; Komarov, V.B.; Aleshin, A.P.; Krylova, T.L. Physical-chemical formation conditions of uranium-titanium-metagel mineralization at the gold-uranium Elkon deposit. Proc. High. Educ. Establ. Geol. Explor. 2017, V, 52-57. [CrossRef]

8. State Service for Geology and Subsoil of Ukraine. 2020. Available online: http://geoinf.kiev.ua (accessed on 1 May 2020).

9. De Oliveira, A.; Fuzikawa, F.; Moura, L.; Raposo, C. Provincia Uranifera de Lagoa Real, Bahia. Princ. Depos. Minerais Bras. 1985, 1, 105-120.

10. Angeiras, A. Geology and metallogeny of the Northeastern Brazil uranium-phosphorous province emphasising the Itataia deposit. Ore Geol. Rev. 1988, 3, 211-225. [CrossRef]

11. Kalayaev, G.I. Mode of Albitite Distribution in Zones of the Ukrainian Shield; Abou-Zied, S., Kerns, G., Eds.; US Dept. of Energy: Washington, DC, USA, 1980; pp. 1-13. 
12. Wilde, A.; Otto, A.; Jory, J.; Macrae, C.; Pownceby, M.; Wilson, N.; Torpy, A. Geology and mineralogy of uranium deposits from Mount Isa, Australia: Implications for Albitite uranium deposit models. Minerals 2013, 3, 258-283. [CrossRef]

13. Alexandre, P. Mineralogy and geochemistry of the sodium metasomatism-related uranium occurrence of Aricheng South, Guyana. Miner. Depos. 2010, 45, 351-367. [CrossRef]

14. Lobato, L.M.; Fyfe, W. Metamorphism, metasomatism, and mineralisation at Lagoa Real, Bahia, Brazil. Econ. Geol. 1990, 85, 968-989. [CrossRef]

15. Hannan, K.W.; Golding, S.D.; Herbert, H.K.; Krouse, H.R. Contrasting alteration assemblages in metabasites from Mount Isa, Queensland; implications for copper ore genesis. Econ. Geol. 1993, 88, 1135-1175. [CrossRef]

16. Omel'Yanenko, B.I.; Mineyeva, I.G. Pre- and syn-ore vertical zonation in Precambrian uraniferous sodic metasomatites. Int. Geol. Rev. 1982, 24, 422-430. [CrossRef]

17. Tugarinov, A.I. Complex metasomatic uranium deposits. In Albitized Uranium Deposits: Six Articles Translated from Russian Literature; Abou-Zied, S., Kerns, G., Eds.; U.S. Department of Energy: Washington, DC, USA, 1980; pp. 45-53.

18. Hall, S.; Beard, J.; Neymark, L.; Paces, J.; Breit, G.; Zielinski, R.; Johnson, C.; Potter, C.; Aylor, J. Genetic Model. for the Coles Hill Uranium Deposit, Virginia, USA; United States Geological Survey: Reston, WV, USA, 2020; in press.

19. Gregory, M.J.; Wilde, A.R.; Jones, P.J. Uranium deposits of the Mount Isa region and their relationship to deformation metamorphism and copper deposition. Econ. Geol. 2005, 100, 537-546. [CrossRef]

20. Tappa, M.J.; Ayuso, R.A.; Bodnar, R.J.; Aylor, J.G.; Beard, J.; Henika, W.S.; Vázquez, J.A.; Wooden, J.L.; Poblete, J.A.; Bissig, T.; et al. Age of host rocks at the coles hill uranium deposit, Pittsylvania County, Virginia, based on zircon U-Pb geochronology. Econ. Geol. 2013, 109, 513-530. [CrossRef]

21. Havelcová, M.; Machovič, V.; René, M.; Sýkorová, I.; Lapčák, L.; Špaldoňová, A. Geochemistry of shear zone-hosted uranium mineralisation at the Zadní Chodov uranium deposit (Bohemian Massif). Ore Geol. Rev. 2020, 120, 103428. [CrossRef]

22. Polito, P.; Kyser, K.; Stanley, C. The proterozoic albitite-hosted Valhalla uranium deposit, Queensland, Australia: A description of the mineralisation in diamond drillhole V39. Min. Dep. 2007, 44, 11-40. [CrossRef]

23. Shumlyanskyy, L.; Hawkesworth, C.J.; Billström, K.; Bogdanova, S.; Mytrokhyn, O.; Romer, R.; Dhuime, B.; Claesson, S.; Ernst, R.; Whitehouse, M.; et al. The origin of the Palaeoproterozoic AMCG complexes in the Ukrainian shield: New U-Pb ages and Hf isotopes in zircon. Precambrian Res. 2017, 292, 216-239. [CrossRef]

24. Shumlyanskyy, L.; Mytrohin, O.; Bogdanova, S.; Bratchuk, O.; Yakubenko, P. U-Pb zircons isotopic age of the Korsun-Novomyrgorod Anorthosite-Rapakivi-granite pluton. Geol. Ukr. 2008, 1-2, 77-85. (In Ukrainian)

25. Emetz, A.V.; Donsky, M.O.; Cuney, M.; Vyshnevsky, O.A.; Moroz, V.S.; Proskurko, L.I. Conditions of formation of uranium deposits in sodium metasomatites in the Ukrainian Shield. Geochem. Ore Form. 2008, 26, 95-101.

26. Scherbak, N.P.; Artemenko, G.V.; Lesnaya, I.M.; Ponomarenko, A.N.; Shumlansy, L.V. Geochronology of Early Precambrian of the Ukrainian Shield Proterozoic; Naukova Dumka Press: Kiev, Ukraine, 2008. (In Russian)

27. Lobato, L.M.; Pimentel, M.M.; Cruz, S.C.; Machado, N.; Noce, C.M.; Alkmim, F.F. U-Pb geochronology of the Lagoa Real uranium district, Brazil: Implications for the age of the uranium mineralization. J. South. Am. Earth Sci. 2015, 58, 129-140. [CrossRef]

28. Cordani, U.G.; Iyer, S.S.; Taylor, P.N.; Kawashita, K.; Sato, K.; McReath, I. Pb-Pb, Rb-Sr, and K-Ar systematics of the Lagoa Real uranium province (south-central Bahia, Brazil) and the Espinhao cycle (ca. 1.5-1.0 Ga). J. South. Am. Earth Sci. 1992, 5, 33-46. [CrossRef]

29. Turpin, L.; Maruéjol, P.; Cuney, M. U-Pb, Rb-Sr and Sm-Nd chronology of granitic basement, hydrothermal albitites and uranium mineralization (Lagoa Real, South-Bahia, Brazil). Contrib. Miner. Pet. 1988, 98, $139-147$. [CrossRef]

30. Chaves, A.O.; Tubrett, M.; Rios, F.; Oliveira, L.; Alves, J.; Fuzikawa, K.; Neves, J.; Matos, E.; Chaves, A.; Prates, S. U-Pb ages related to uranium mineralisation of Lagoa Real, Bahia, Brazil: Tectonic implications. Rev. Geol. 2007, 20, 141-156.

31. Gregory, M.J.; Schaefer, B.F.; Keays, R.R.; Wilde, A. Rhenium-osmium systematics of the Mount Isa copper orebody and the Eastern Creek Volcanics, Queensland, Australia: Implications for ore genesis. Miner. Deposita 2008, 43, 553-573. [CrossRef] 
32. Connors, K.A.; Page, R.W. Relationships between magmatism, metamorphism and deformation in the western Mount Isa Inlier, Australia. Precambrian Res. 1995, 71, 131-153. [CrossRef]

33. Bain, J.; Heinrich, C.A.; Henderson, G.A.M. Stratigraphy, structure and metasomatism of the haslingdon group, East Moondarra Area, Mt Isa: A deformed and mineralised proterozoic multistage rift-sag sequence. In Detailed Studies of the Mount Isa Inlier, AGSO; Blake, D.H., Stewart, A.J., Eds.; Australian Geological Survey Organisation: Canberra, Australia, 1992; pp. 125-136.

34. Oliver, N.H.; Cleverley, J.S.; Mark, G.; Pollard, P.; Bin, F.; Marshall, L.; Rubenach, M.; Williams, P.; Baker, T. Modeling the role of sodic alteration in the genesis of iron oxide copper-gold deposits, eastern Mount Isa Block. Aust. Econ. Geol. 2004, 99, 1145-1176. [CrossRef]

35. Duncan, R.J.; Stein, H.J.; Evans, K.A.; Hitzman, M.W.; Nelson, E.P.; Kirwin, D.J. A New geochronological framework for mineralization and alteration in the Selwyn-mount dore corridor, Eastern fold belt, Mount Isa Inlier, Australia: Genetic implications for iron oxide copper-gold deposits. Econ. Geol. 2011, 106, 169-192. [CrossRef]

36. Rubenach, M.; Foster, D.R.W.; Evins, P.M.; Blake, K.; Fanning, C. Age constraints on the tectonothermal evolution of the Selwyn Zone, Eastern Fold Belt, Mount Isa Inlier. Precambrian Res. 2008, 163, 81-107. [CrossRef]

37. Cave, B.; Lilly, R.; Glorie, S.; Gillespie, J. Geology, apatite geochronology, and geochemistry of the Ernest Henry Inter-Lens: Implications for a re-examined deposit model. Minerals 2018, 8, 405. [CrossRef]

38. Hicks, C.L. Petrological and mineralogical investigation of the Michelin Uranium deposit, central mineral belt, Labrador. Master's Thesis, Memorial University, St. John, NL, Canada, 2015; p. 466.

39. Schärer, U.; Krogh, T.E.; Wardle, R.J.; Ryan, B.; Gandhi, S.S. U-Pb ages of early and middle Proterozoic volcanism and metamorphism in the Makkovik Orogen, Labrador. Can. J. Earth Sci. 1988, 25, 1098-1107. [CrossRef]

40. Sparkes, G. Uranium mineralization within the Central Mineral Belt of Labrador: A summary of the diverse styles, settings and timing of mineralization. In Openfile Report LAB/1684; Newfoundland \& Labrador Natural Resources \& Mines: St. Johns, NL, Canada, 2017; p. 198.

41. Hinchey, A.M. The Paleoproterozoic metavolcanic, metasedimentary and igneous rocks of the Aillik Domain, Makkovik Province, Labrador (NTS Map Area 13O/03): Current research, Newfoundland \& Labrador Dept. Nat. Resour. Geol. Surv. Rep. 2007, 1, 25-44.

42. Sparkes, G.W.; Dunning, G.R. Preliminary investigations into the style, setting and timing of uranium mineralization, Jacques Lake deposit, Central Mineral Belt, Labrador. Curr. Res. (2009) Nfld. Labrador Dep. Nat. Res. Geol. Surv. Rep. 2009, 1, 81-93.

43. Wilton, D.H.C.; Longerich, H.P. Metallogenic significance of trace element and U-Pb isotope data for uraninite-rich mineral separates from the Labrador Central Mineral Belt. Can. J. Earth Sci. 1993, 30, 2352-2365. [CrossRef]

44. Culshaw, N.G.; Reynolds, P.H.; Sinclair, G.; Barr, S. Amphibole and mica 40Ar/39Ar ages from the Kaipokok and Aillik domains, Makkovik Province, Labrador: Towards a characterization of back-arc processes in the Paleoproterozoic. Can. J. Earth Sci. 2002, 39, 749-764. [CrossRef]

45. McGloin, M.; Tomkins, A.G. Release of uranium from highly radiogenic zircon through metamictization: The source of orogenic uranium ores: Reply. Geology 2016, 44, e404. [CrossRef]

46. Zhong, J.; Wang, S.-Y.; Gu, D.-Z.; Cai, Y.-Q.; Fan, H.-H.; Shi, C.-H.; Hu, C.-N. Geology and fluid geochemistry of the Na-metasomatism $U$ deposits in the Longshoushan uranium metallogenic belt, NW China: Constraints on the ore-forming process. Ore Geol. Rev. 2020, 116, 103214. [CrossRef]

47. Cuney, M. Release of uranium from highly radiogenic zircon through metamictization: The source of orogenic uranium ores: Comment. Geology 2016, 44, e403. [CrossRef]

48. Lobato, L.M.; Forman, J.M.; Fyfe, W.S.; Kerrich, R.; Barnett, R.L. Uranium enrichment in archean crustal basement associated with overthrusting. Nature 1983, 303, 235-237. [CrossRef]

49. Fuzikawa, K.; Alves, J.V. Dilatacao de inclusoes fluidas em palgioclasos da provincia uranifera de Lagoa real-caetite, BA. Cong. Bras. Geol. 1984, 3, 4453-4462.

50. De Souza, A. Inclusoes Fluidas nos Minerales Associados a Mineralizacao Uranifera da Jazida do Engehno (Anomalia 09), Provincia Uranifera de Lagoa Real, Bahia. Master's Thesis, Centro de Desenvolvimento da Technologia Nuclear, Belo Horizonte, Brazil, 2009; p. 135. 
51. Fuzikawa, K.; Alves, J.V.; Maruejol, P.; Cuney, M.; Kostolanyi, B.; Poty, B. The Lago Real Uranium Province, Bahia State, Brazil. Some petrographic aspects and fluid inclusion studies. Geochim. Bras. 1988, 2, 109-118.

52. Belevstev, N.Y.; Koval, V.B.; Lalko, V.I.; Bloh, A.M.; Zhukov, F.I.; Nikolayenko, V.I. Metamorphogenic Ore Formation in Precambrian: Physico-chemical Basis for Theory of Metamorphogenic Ore Formation; Naukova Dumka Press: Kiev, Ukraine, 1985. (In Russian)

53. Fomin, Y.A.; Korostyskevsky, Y.Z. Dependence of carbon and oxygen isotopic contents in carbonates on their temperature (in Zones of Alkali calcareous metasomatism). Rep. Nat. Acad. Sci. USSR 1986, 28-30. (In Russian)

54. Cinelu, S.; Cuney, M. Sodic metasomatism and U-Zr mineralization: A model based on the Kurupung batholith (Guyana). Geochim. Cosmochim. Acta 2006, 70, A103. [CrossRef]

55. Cox, S.; Etheridge, M. Coupled grain-scale dilatancy and mass transfer during deformation at high fluid pressures: Examples from Mount Lyell, Tasmania. J. Struct. Geol. 1989, 11, 147-162. [CrossRef]

56. Oliver, N.H.S. Linking of regional and local hydrothermal systems in the mid-crust by shearing and faulting. Tectonophysics 2001, 335, 147-161. [CrossRef]

57. Connors, K.A.; Lister, G.S. Polyphase deformation in the western Mount Isa Inlier, Australia: Episodic or continuous deformation? J. Struct. Geol. 1995, 17, 305-328. [CrossRef]

58. Oliver, N.H.S.; McLellan, J.; Hobbs, B.E.; Cleverley, J.; Ord, A.; Feltrin, L. 100th Anniversary special paper: Numerical models of extensional deformation, heat transfer, and fluid flow across basement-cover interfaces during basin-related mineralization. Econ. Geol. 2006, 101, 1-31. [CrossRef]

59. Cui, T.; Yang, J.; Samson, I.M. Tectonic deformation and fluid flow: Implications for the formation of unconformity-related uranium deposits. Econ. Geol. 2012, 107, 147-163. [CrossRef]

60. Rene, M.; Dolnicek, Z. Uraninite, coffinite and brannerite on shear-zone coupled uranium deposits of the Bohemian Massif (Central European Variscan Belt). Minerals 2017, 7, 50. [CrossRef]

61. Morrissey, L.J.; Tomkins, A.G. Evaporite-bearing orogenic belts produce ligand-rich and diverse metamorphic fluids. Geochim. Cosmochim. Acta 2020, 275, 163-187. [CrossRef]

Publisher's Note: MDPI stays neutral with regard to jurisdictional claims in published maps and institutional affiliations.

(C) 2020 by the author. Licensee MDPI, Basel, Switzerland. This article is an open access article distributed under the terms and conditions of the Creative Commons Attribution (CC BY) license (http://creativecommons.org/licenses/by/4.0/). 